\title{
Ichthyofauna of the Parnaíba river Basin, Northeastern Brazil
}

\author{
Telton Pedro Anselmo Ramos ${ }^{1,2}$, Robson Tamar da Costa Ramos ${ }^{I}$ \& Stéfane Almeida Q.A. Ramos ${ }^{I}$ \\ ${ }^{1}$ Laboratório de Sistemática e Morfologia de Peixes, Departamento de Sistemática e EcologialCCEN, \\ Universidade Federal da Paraíba, Campus I, João Pessoa, PB, CEP: 58059-900 \\ ${ }^{2}$ Corresponding author: Telton P.A. Ramos, e-mail: telton@gmail.com
}

\begin{abstract}
RAMOS, T.P.A., RAMOS, R.T.C., RAMOS, S.A.Q.A. Ichthyofauna of the Parnaíba river Basin, Northeastern Brazil. Biota Neotropica. 14(1): e20130039. www.biotaneotropica.org.br/v14n1/en/abstract?inventory+bn01014012014
\end{abstract}

\begin{abstract}
The Parnaíba River is the largest hydrographic basin with its limits entirely within the northeastern region of Brazil. It is one of the few perennial rivers in the Brazilian Northeastern Region, running predominantly in the area of Caatinga on the eastern portion (with intermittent drainages associated to this type of environment), and partly extending into the Cerrado region on the western portion. The objective of this study was to describe the diversity of freshwater fishes of the Parnaíba River basin by conducting a comprehensive ichthyofauna inventory of the basin. The sampling design of this study was based on the placement of (1) Fixed Sites for seasonal collection (dry and wet season, two years) in the three portions of the main course of the Parnaíba River, and (2) "Aquarap" protocol collections which covered the entire basin. The collection effort consisted of 244 sampling sites surveyed along the entire basin between the years 2004 and 2011. Fish were collected with the use of seines, cast nets, gill nets and dip nets; only the first two fishing gears were used in Fixed Sites. As a result, 146 species of freshwater fish were recorded in the Parnaíba River basin, distributed in 103 genera, 36 families and 11 orders. The registered endemism reached a total of 54 species.
\end{abstract}

Keywords: Parnaiba River, Ichthyofauna, Northeastern Brazil, Neotropical Region.

RAMOS, T.P.A., RAMOS, R.T.C., RAMOS, S.A.Q.A. Ictiofauna da bacia do Parnaíba, Nordeste do Brasil. Biota Neotropica. 14(1): e20130039. http://www.biotaneotropica.org.br/v14n1/pt/abstract?inventor$\mathrm{y}+\mathrm{bn} 01014012014$

Resumo: O rio Parnaíba é o maior rio cuja bacia hidrográfica está inteiramente situada na região Nordeste do Brasil. É um dos poucos rios perenes do Nordeste e encontra-se sob domínio predominante de Caatinga (com drenagens intermitentes associadas a este tipo de ambiente), uma parte estendendo-se em região de Cerrado. Este estudo descreveu a diversidade da ictiofauna de água doce da bacia do rio Parnaíba através da realização de um amplo inventário. O desenho amostral baseou-se no estabelecimento de (1) Pontos Fixos de coleta sazonal (seca e cheia, dois anos de coleta) nas três porções do curso principal do rio Parnaíba, e (2) coletas do tipo "AquaRap", que cobriram toda a bacia. O esforço de coleta somou 244 pontos visitados ao longo da bacia entre os anos de 2004 e 2011 . Os peixes foram coletados com o uso de redes de arrasto, tarrafas, esperas e puçás; apenas os dois primeiros tipos de apetrechos foram utilizados nos Pontos Fixos. Como resultado, foram registradas 146 espécies de peixes de água doce na bacia do rio Parnaíba, distribuídas em 103 gêneros, 36 famílias e 11 ordens; o endemismo registrado foi de 54 espécies.

Palavras-chave: Rio Parnaíba, Ictiofauna, Nordeste brasileiro, região Neotropical..

\section{Introduction}

Most basins in Northeastern Brazil are under the influence of the Caatinga. This biome is characterized by low rainfall, high evaporation rate and hence intermittent rivers, except for the main course of the São Francisco and Parnaíba rivers, which are perennials (Rosa et al. 2003). The Parnaíba River, object of this study, is the largest river in Northeastern Brazil among those whose drainage extends completely into this region, running on the north-western portion of the Caatinga, and is part of the Maranhão-Piauí ecoregion. Only a small part of its drainage is associated with the Cerrado area (Rosa et al. 2003).

The volume of information related to the fish fauna of the Parnaíba River basin is limited, although its exploration has begun in the nineteenth century, with Johan von Spix and Karl von Martius (Ramos 2012). This basin was included in the "Thayer Expedition", lead by Louis Agassiz. The collection at the Parnaíba basin, however, was done by Orestes St. John. After studying Parnaiba's specimens Agassiz focused on the similarities between the ichthyofauna of this basin and that of the Amazon basin, being the first author to state that the 
Parnaíba basin, under the geological and zoological viewpoints seems to be part of the Amazon basin (Agassiz \& Agassiz, 1875). Géry (1969) agreed with the preceding authors in considering the Parnaíba basin as part of the "Amazon faunistic region", and Paiva (1978) followed this statement adding that its ichthyofauna was impoverished. Rosa et al. (2003) refuted this last statement, referring to a higher number of species and endemism, and also highlighted that the Parnaíba river basin shares some similar species with the Amazonian basin. Vari (1989) cited some examples of the close relationship between the ichthyofauna of these two basins, such as the genus Psectrogaster, whose species occurring at the Parnaíba River is the sister-taxon of a species occurring at the Amazon basin.

Fowler (1941, 1954), Menezes (1955), Roberts (1968), Paiva (1973), Fontanele \& Farias (1979), Barbosa (1981) and Soares (1987) compiled lists of freshwater fish species of the Parnaíba River; and fisheries at the Parnaíba River were addressed during the 60's and 70's by Menezes $(1964,1973)$ and Paiva (1973, 1976). These papers provided lists of the freshwater fish species occurring in the basin in which 50-80 species were cited. These lists were biased on citing mostly middle to large-sized species (i.e., those targeted by the fishermen) and are now also largely outdated with respect to the taxonomy (Ramos 2012). In the last decade were described nine new species of freshwater fish of the Parnaíba River basin. This scenario shows that the Parnaíba River basin is still poorly known ichthyologically. A more in-depth analysis currently in preparation by the authors point that the level of endemism of the Parnaiba River basin is even higher than the present estimate indicates. Other recent studies have demonstrated a low level of knowledge on the taxonomy of the Parnaíba River ichthyofauna. For example, Staeck \& Shindler (2006) described Geophagus parnaibae based on specimens traditionally identified as $G$. surinamensis; Piorski et al. (2008) described Platydoras brachylecis based on specimens identified as $P$. costatus. The aim of this study was to describe the diversity of freshwater fishes of the Parnaíba River basin through an extensive inventory.

\section{Material and Methods}

\section{Study area}

The main course of the Parnaíba River (Figure 1) has a south-north direction, with large meanders along its course. The low water period spans from June to October, the raining season from November to May; and large floods occur in January and February (SEMAR-PI; SRH/MMA. 2008). The main river course has a length of $1400 \mathrm{~km}$, with the entire basin covering an area of $344.112 \mathrm{~km}^{2}(3.9 \%$ of Brazilian territory) and draining nearly the entire Piauí State ( $99 \%$ of the territory), part of Maranhão (19\%) and Ceará (10\%) States. The main channel extends between Maranhão and Piauí States, defining the border between them in its entire length. The Parnaíba River basin includes 143 tributaries on the Piauí side, and 74 on the Maranhão side; part of tributaries on the east margin have their headwaters in Ceará State. The main tributaries of the
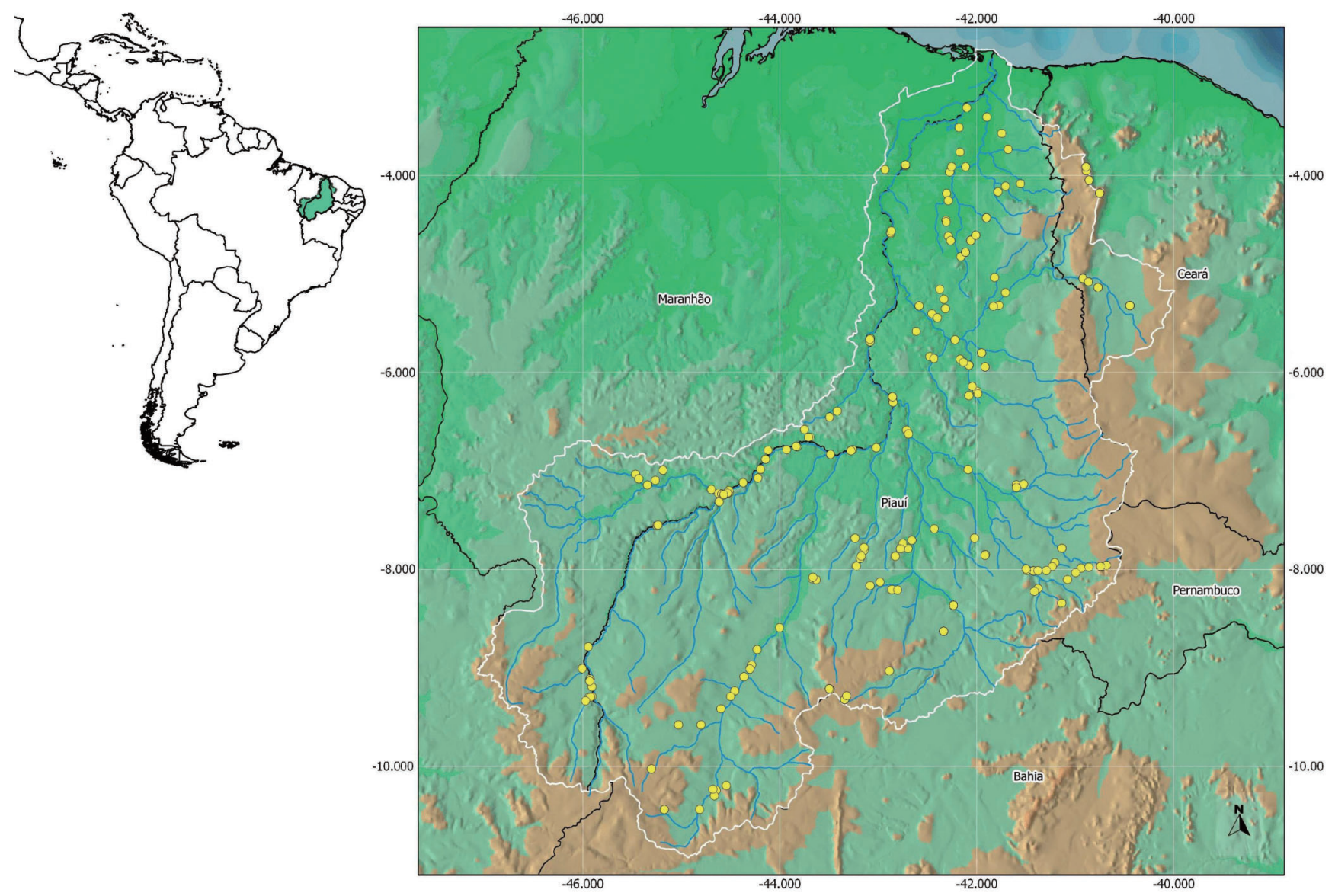

Figure 1. Map of the Parnaíba River basin showing the geographical location of the study's sampling sites (see Sample Design). The marks on the map may represent more than one collection site. 
Parnaíba river are: the Balsas River (Maranhão side); Poti and Portinho Rivers (Piauí side, with headwaters in Ceará State); Caninde, Piauí, Gurguéia, and Longá Rivers running exclusively in Piauí State. The Parnaíba River has a perennial regime, despite of intermittent tributaries, and represents the transition zone between the Caatinga's semi-arid land in the east area of the basin, and the more humid climate of Cerrado, in the west (Rosa et al. 2003, Ramos 2012).

\section{Sampling Design}

The sampling design of this study was based on the establishment of (1) Fixed Sites for seasonal collection (nine groups of three sites, totalizing 27 collection sites, dry and wet season, from 2009 to 2011), restricted to the main course of the river through its three sections: high, medium and low regions; and (2) AquaRap collections performed between 2004 and 2011, which covered the entire basin. The collection effort conducted in this study consisted in 244 sampling sites along the entire river basin (Figure 1). As a freshwater fish study, it has excluded the area of the basin under marine influence. Additionally, reliable data from the literature were also considered for the compilation of the present list.

\section{Collection and identification of specimens}

Fishes were collected with seines (seines $20 \mathrm{~m}$ long, $2.5 \mathrm{~m}$ high, mesh size $10 \mathrm{~mm}$; seines $4 \mathrm{~m}$ long, $2 \mathrm{~m}$ height, mesh size $5 \mathrm{~mm})$, castnets ( $2 \mathrm{~m}$ height, mesh size $15 \mathrm{~mm}$ ), gillnets of various mesh sizes $(15,25,35,45$ and $55 \mathrm{~mm})$, and dip nets (mesh size 5 and $10 \mathrm{~mm}$ ). The ichthyological material obtained in the samples was fixed in the field into a $10 \%$ formalin solution neutralized with sodium tetraborate. Some specimens were photographed alive in order to obtain records of natural coloration. Specimens were treated according to the rules of scientific curation following Malabarba \& Reis (1987). Sorting and identification of specimens were carried out at the Laboratório de Sistemática e Morfologia de Peixes of Universidade Federal da Paraíba. This ichthyological material was deposited into the Ichthyological Collection of the Departamento de Sistemática e Ecologia of the same university.

Meristic and morphometric data were taken according to Hubbs \& Lagler (2006). The systematic list follows Nelson (2006).

\section{Results and Discussion}

\section{Ichthyofauna}

This study recorded 146 species of freshwater fish in the Parnaíba River basin, belonging to 103 genera, 36 families and 11 orders (Table 1). The number of 146 species recorded in the present work exceeds by more than 40 the assumption of the richness of the Parnaíba River freshwater fish fauna by Abell et al. (2008), who proposed between 67 and 101 species, this being the largest number of supposed species found in the basin, among the propositions reported in the literature.

The order of fish with the greatest number of species occurring in the Parnaíba River basin was Characiformes, with 59 species, representing $40 \%$ of the recorded species. The species of the order Characiformes are distributed in 40 genera and 12 families. The second more representative order was Siluriformes, with 48 species in 30 genera and 8 families, representing $33 \%$ of the species (Figure 2). The families with the
Table 1. List of species of freshwater fish of the Parnaíba River basin analyzed on this study: ${ }^{(E)}$ Endemic Species; ${ }^{(I)}$ Introduced species; ${ }^{(L)}$ record from the literature (not confirmed by this study - literature source: ${ }^{[1]}$ Reis et al., 2003; ${ }^{[2]}$ Rosa et al. (2003); ${ }^{[3]}$ Buckup et al., 2007); ${ }^{(\mathrm{NR})}$ New Record.)

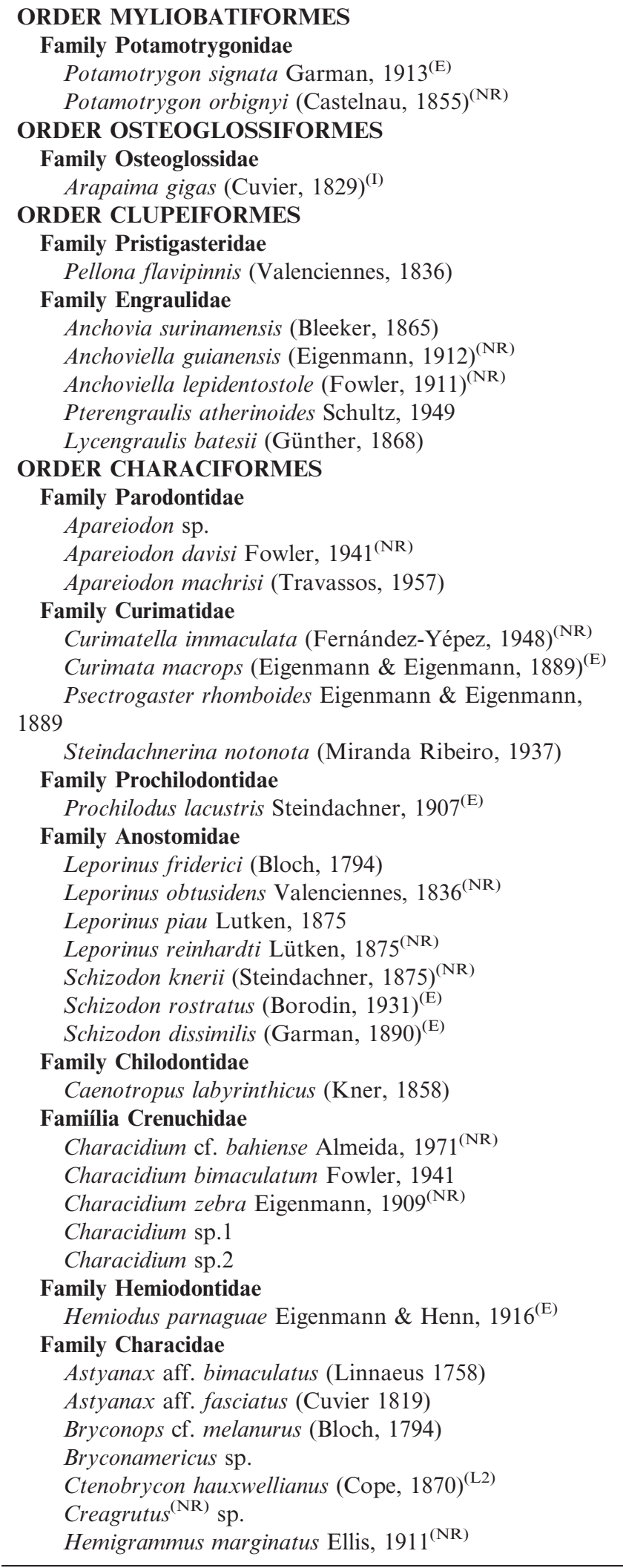

Continued on next page 
Table 1. Continued.

Hemigrammus sp.

Hyphessobrycon sp. 1

Hyphessobrycon sp. 2

Gymnocorymbus thayeri Eigenmann, $1908^{(\mathrm{L} 2)}$

Jupiaba polylepis (Günther, 1864) ${ }^{(\mathrm{NR})}$

Knodus victoriae (Steindachner, 1907) ${ }^{(\mathrm{E})}$

Moenkhausia $\mathrm{sp.}$

Moenkhausia lepidura (Kner, 1858) ${ }^{\text {(L2) }}$

Moenkhausia sanctaefilomenae (Steindachner, 1907)

Psellogrammus kennedyi (Eigenmann, 1903) ${ }^{(\mathrm{NR})}$

Phenacogaster calverti (Fowler, 1941)

Roeboides margareteae Lucena, 2003 ${ }^{(\mathrm{E})}$

Roeboides sazimai Lucena, $2007^{(\mathrm{E})}$

Brachychalcinus parnaibae Reis, $1989^{(\mathrm{E})}$

Poptella compressa (Günther, 1864)

Tetragonopterus argenteus Cuvier, 1816

Compsura heterura Eigenmann, 1915

Serrapinnus heterodon (Eigenmann, 1915)

Serrapinnus piaba (Lütken, 1875)

Serrapinnus sp.

Family Serrasalmidae

Colossoma macropomum (Cuvier, 1816) ${ }^{(\mathrm{I})}$

Metynnis lippincottianus (Cope, 1870)

Myleus asterias (Müller \& Troschel, 1844)

Mylossoma aureum (Agassiz, 1829) ${ }^{(\mathrm{L} 2)}$

Pygocentrus nattereri Kner, 1858

Serrasalmus rhombeus Lütken, 1875

Family Triportheidae

Triportheus signatus (Garman 1890)

Family Acestrorhynchidae

Acestrorhynchus falcatus (Bloch, 1794)

Family Erythrinidae

Hoplerythrinus unitaeniatus (Spix \& Agassiz, 1829)

Hoplias malabaricus (Bloch, 1794)

\section{ORDER SILURIFORMES}

Family Trichomycteridae Ituglanis $^{(\mathrm{NR})} \mathrm{sp}$.

Family Callichthyidae

Callichthys callichthys (Linnaeus, 1758)

Hoplosternum littorale (Hancock, 1828)

Aspidoras raimundi (Steindachner, 1907) ${ }^{(\mathrm{E})}$

Corydoras julii Steindachner, 1906

Corydoras treitlii Steindachner, 1906 ${ }^{(\mathrm{E})}$

Corydoras vittatus Nijssen, 1971

Family Loricariidae

Otocinclus hasemani Steindachner, 1915

Parotocinclus cearensis Garavello, $1977^{(\mathrm{NR})}$

Parotocinclus haroldoi Garavello, $1988^{(\mathrm{E})}$

Parotocinclus sp.

Limatulichthys griseus Eigenmann, $1909^{(\mathrm{L} 1,3)}$

Loricaria parnahybae Steindachner, 1907

Loricaria sp.

Loricariichthys derbyi Fowler, 1915

Rineloricaria $^{(\mathrm{NR})} \mathrm{sp}$.

Ancistrus damasceni (Steindachner, 1907) ${ }^{(\mathrm{E})}$

Ancistrus sp.1

Ancistrus sp. 2

Hypostomus johnii (Steindachner, 1877) ${ }^{(\mathrm{E})}$
Table 1. Continued.

Hypostomus sp. 1

Hypostomus sp. 2

Hypostomus sp. 3

Hypostomus sp. 4

Pterygoplichthys parnaibae (Weber, 1991) ${ }^{(\mathrm{E})}$

Family Aspredinidae

Aspredo aspredo (Linnaeus, 1758)

Family Heptapteridae

Imparfinis $^{(\mathrm{NR})} \mathrm{sp}$.

Pimelodella parnahybae Fowler, $1941^{(\mathrm{E})}$

Pimelodella cf. steindachneri Eigenmann, 1917

Phenacorhamdia $^{(\mathrm{NR})} \mathrm{sp}$.

Rhamdia quelen (Quoy \& Gaimard, 1824)

Family Doradidae

Hassar affinis (Steindachner, 1881) ${ }^{(\mathrm{E})}$

Platydoras brachylecis Piorski, Garavello, Arce H. \&

Sabaj Pérez, 2008

Family Auchenipteridae

Ageneiosus inermis (Linnaeus, 1766)

Ageneiosus sp.

Auchenipterus menezesi Ferraris \& Vari, 1999(E)

Trachelyopterus galeatus (Linnaeus, 1766)

Family Pimelodidae

Brachyplatystoma filamentosum (Lichtenstein, 1819)

Brachyplatystoma vaillantii (Valenciennes, 1840)

Hemisorubim platyrhynchos (Valenciennes, 1840)

Hypophthalmus cf. edentatus Spix \& Agassiz, $1829^{(\mathrm{NR})}$

Pimelodus blochii Valenciennes, 1840

Pimelodus maculatus La Cepède, 1803

Pimelodus ornatus Kner, 1858

Pimelodus sp. 1

Pimelodus sp. 2

Pseudoplatystoma fasciatum (Linnaeus, 1766)

Sorubim lima (Bloch \& Schneider, 1801)

ORDER GYMNOTIFORMES

Family Gymnotidae Gymnotus carapo Linnaeus, 1758

Family Hypopomidae Brachypopomus $^{(\mathrm{NR})} \mathrm{sp}$.

Family Rhamphichthyidae Rhamphichthys marmoratus Castelnau $1855^{(\mathrm{NR})}$

Family Sternopygidae

Eigenmannia macrops (Boulenger 1897) ${ }^{(\mathrm{NR})}$

Eigenmannia virescens (Valenciennes, 1842)

Sternopygus macrurus (Bloch \& Schneider, 1801)

Family Apteronotidae

Apteronotus sp.

ORDER BELONIFORMES

Family Belonidae

Pseudotylosurus microps (Günther, 1866)

ORDER CYPRINODONTIFORMES

Family Rivulidae

Cynolebias parnaibensis Costa, Ramos, Alexandre \&

Ramos, 2010 ${ }^{\text {(E) }}$ $2013^{\text {(E.) }}$

Hypsolebias coamazonicus Costa, Amorim \& Bragança,

Pituna schindleri Costa, $2007^{(\mathrm{E})}$

Melanorivulus parnaibensis (Costa, 2003) $)^{(\mathrm{E})}$ 
Table 1. Continued.

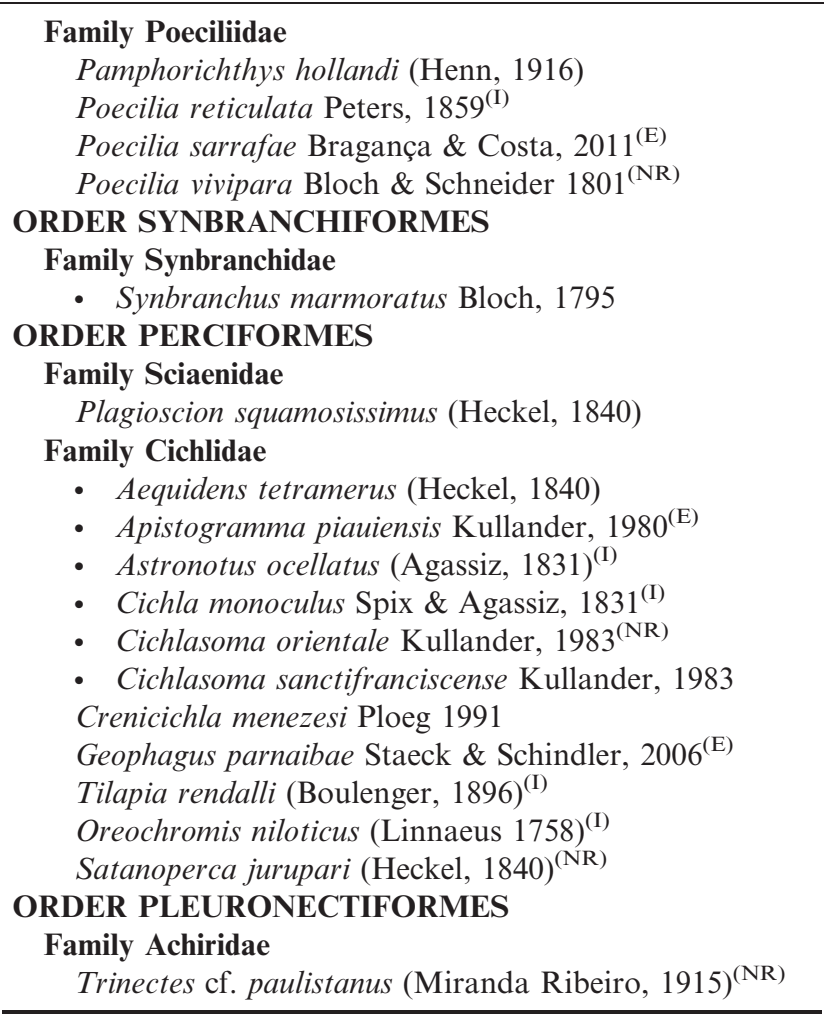

highest number of species was Characidae, with 27 species, representing $18 \%$ of the species, followed by Loricariidae, with 18 species $(12 \%)$, Cichlidae and Pimelodidae, with $11(8 \%)$ species each (Figure 3). This result is in agreement with previous studies conducted on Northeastern region of Brazil (Rosa et al., 2003, Ramos et al. 2005), but also when considered the whole Brazil (Buckup et al. 2007) or the Neotropical region (Reis et al. 2003). The presence of Pimelodidae among the four families with the largest number of species in the Parnaíba River basin follows the recorded pattern for the Caatinga, as stated by Rosa et al. (2003). This family is not registered within those with the largest number of species in the List of freshwater fish of Brazil (Buckup et al. 2007) and that of Neotropical region (Reis et al. 2003), corroborating this pattern as characteristic of the Caatinga biome. Fifteen families were represented with only one species.

Among the 146 species recorded in this study, 27 are new records for the basin, five are recorded only by the literature (not collected in this study), seven are introduced species, and other 27 are undescribed species. The 27 new records in the Parnaíba basin, cited above, may include undescribed species, but more study is necessary before sorting out which species are truly undescribed and which are already known. This is the case, for example, of the specimens preliminarily identified as Characidium cf. bahiense, referred to species whose occurrence is restricted to coastal rivers of Bahia State, and situated east of the São Francisco basin.

\section{Endemism}

Eigenmann (1910) has listed only 19 species of freshwater fish in the Parnaíba River; Menezes (1955) recorded 93 species.

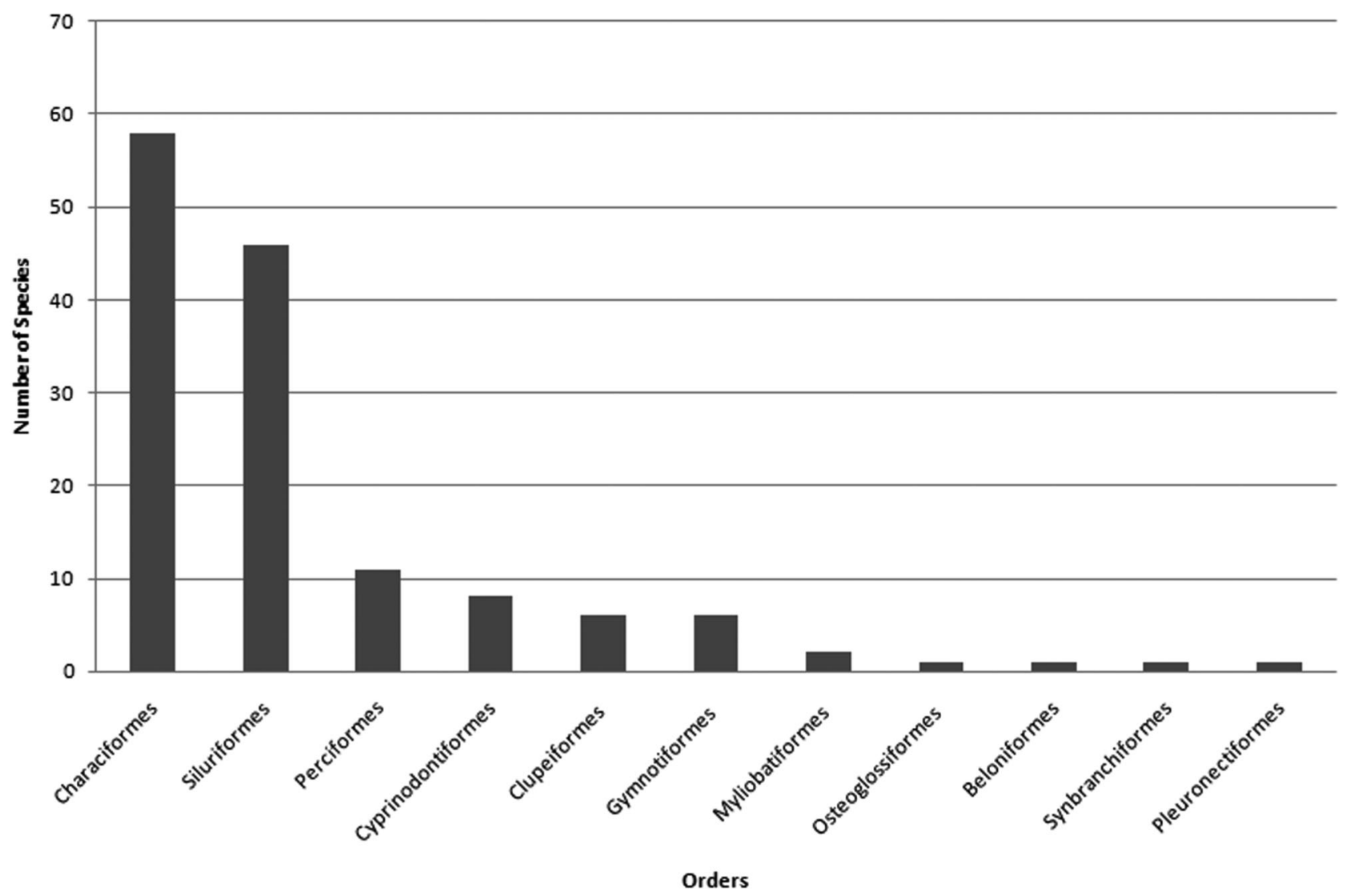

Figure 2. Number of species recorded by order in the Parnaíba River basin between 2004 and 2011. 
Ramos, T.P.A. et al

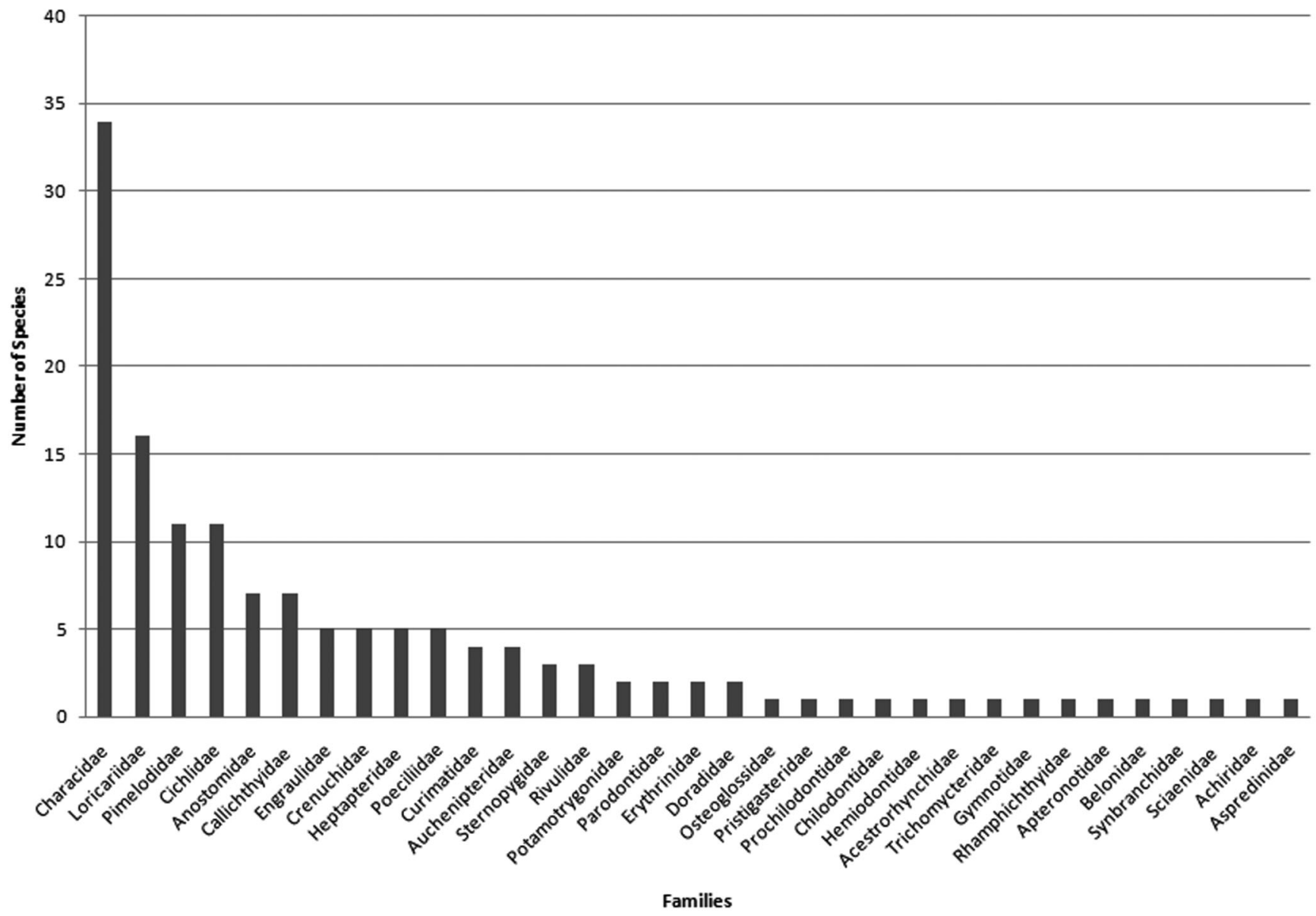

Figure 3. Number of species recorded per family in the Parnaíba River basin between 2004 and 2011.

According to Roberts (1968) and Paiva (1978) the fish fauna of the Parnaíba River would consist of 80 to 100 species, but with low level of endemism. Rosa et al. (2003) counted 86 species for the Maranhão-Piauí Region (which includes the Parnaíba basin) with 15 possible endemic species $(17.5 \%$ of the fish fauna). Hubert \& Renno (2006) considered the Parnaíba River basin as one of the 11 basins diagnosed as areas of endemism in South America, when analyzing the biogeographic history of the freshwater fishes of this region. According to the above cited authors the Parnaíba River basin would have a fish fauna consisting of 24 species, 8 endemic. Abell et al. (2008) consider the Parnaíba River basin as one of the 44 ecoregions of tropical South America and estimate the species richness of the basin between 67 and 101 and from 12 to 19 the number of endemic species (around 15 to 21\%). Albert \& Reis (2011) state that the species richness of the Parnaíba River would be around 95 species, 20 endemic. However, Pinna \& Wosiacki (2003), stressed that the Parnaíba basin is poorly sampled and that the low level of endemism recorded in this basin at that time would be related to the restricted number of samples, especially in the upper portion of the basin.

The authors above mentioned, who worked during the second half of the $20^{\text {th }}$ century and in the $21^{\text {st }}$ century, registered between 67-101 species in the Parnaíba River basin, a number notably beneath that recorded in this study, 146 species. Over the past decade, new species endemic to the Parnaíba basin have been described: Roeboides margareteae Lucena 2003,
Melanorivulus parnaibensis (Costa 2003), Geophagus parnaibae Staeck \& Schindler 2006, Pituna schindleri Costa 2007, Roeboides sazimai Lucena 2007, Platydoras brachylecis Piorski, Garavello, Arce H. \& Sabaj Pérez, 2008, Cynolebias parnaibensis Costa, Ramos, Alexandre \& Ramos, 2010, Poecilia sarrafae Bragança \& Costa 2011 e Hypsolebias coamazonicus Costa, Amorim \& Bragança, 2013. Adding these taxa to those 27 undescribed taxa detected in the present study, the record of endemism in Parnaíba River basin is increased by 36 species. The endemism data referred by Rosa et al. (2003) and distribution by Reis et al. (2003) and Buckup et al. (2007), together with those registered in the present study increase the number of freshwater fish species endemic to the Parnaíba basin to 54 species, 34 more than the highest number of endemic species previously proposed as occurring in the Parnaíba basin (20 species, Albert \& Reis, 2011). The 54 endemic species represent $38.9 \%$ of the 139 native species diagnosed in the present work. Again, it is necessary to emphasize that the headwaters of this basin were not yet thoroughly sampled.

\section{Final Remarks}

The present study is the most comprehensive survey from the Parnaíba River to date and considerably increased our knowledge about its freshwater fish fauna. However, some gaps in the knowledge of this fish fauna still remain. First, the headwaters of the basin still need to be adequately surveyed. Also, more studies are necessary to understand the relation- 
ships of the species occurring in the Parnaíba River with species from other river systems, which depend on a better assessment of the taxonomy of several fish groups. The present study is an initial step towards a full account on the fish diversity of this biogeographically important river basin.

\section{Acknowledgments}

The authors are grateful to Márcio Joaquim Silva, Ludmila Antunes, Willian Severi, Elton França, Airton Carvalho, Paula Honório, Anderlechi Silva, Yuri Ponce, Sônia Nóbrega, Guilherme Moro, Patrícia Charvet, Telmy Paulo Anselmo and José Aparecido do Nascimento for help with field work. Heraldo Britski, Naércio Menezes, Flavio Lima, Claudio Zawadzki, Monica Toledo, Wilson Costa, Carla Pavanelli and Andréia Paixão offered their expertise in specimens identification. This study was supported by CNPq (Conselho Nacional de Desenvolvimento Científico e Tecnológico). Collections were made under permit 20088-3/2009 MMA/ ICMBio/SISBIO from Ministério do Meio Ambiente/Instituto Chico Mendes de Conservação da Biodiversidade/Sistema de Autorização e Informação em Biodiversidade.

\section{References}

ABELL，R., THIEME，M.L., REVENGA，C.,BRYER, M., KOTTELAT, M., BOGUTSKAYA, N., COAD, B., MANDRAK, N., CONTRERAS BALDERAS, S., BUSSING, W.,STIASSNY, M.L. J.,SKELTON, P.,ALLEN, G.R.,UNMACK, P.,NASEKA, A.,NG, R.,SINDORF, N.,ROBERTSON, J.,ARMIJO, E.,HIGGINS, J.V.,HEIBEL, T.J.,WIKRAMANAYAKE, E.,OLSON, D.,LÓPEZ, H. L.,REIS, R. E.,LUNDBERG, J.G.,SABAJ PÉREZ, M. H., \& PETRY, P. 2008. Freshwater ecoregions of the world: a new map of Biogeographic units for freshwater biodiversity conservation. Bioscience. 58(5):403-414. doi: http://dx.doi.org/10.1641/ B580507

AGASSIZ, L. \& AGASSIZ. E.C. 1975. Viagem ao Brasil: 1865-1866. Tradução de João Etienne Filho. Ed. da Universidade de São Paulo, São Paulo.

ALBERT, J.S. \& REIS, R.E.2011. Historical Biogeography of Neotropical Freshwater Fishes.University of California Press. London. England, p.1- 406.

BARBOSA, J.M. 1981. Sobre a Ictiofauna da bacia do rio Parnaíba. Boletim do Centro de Ciências da Natureza/UFPI, v. 2, n. 2, p. 7882.

BRAGANÇA, P.H.N. \& COSTA, W.J.E.M. 2011. Poecilia sarrafae, a new poeciliid species from Parnaíba and Mearim river basins, northeastern Brazil (Cyprinodontiformes: Cyprinodontoidei). Ichthyological Exploration of Freshwaters, v. 21, p. 369-376.

BUCKUP, P.A., MENEZES, N.A. \&GHAZZI, M.S. 2007.Catálogo das Espécies de Peixes de Água Doce do Brasil. Rio de Janeiro: Museu Nacional. p.1-195.

COSTA, W.J.E.M. 2003. A new species of the genus Rivulus Poey, 1860 from the Parnaiba river basin, northeastern Brazil (Teleostei, Cyprinodontiformes, Rivulidae). Boletim do Museu Nacional, Rio de Janeiro, 511:1-7.

COSTA, W.J.E.M. 2007.Taxonomy of the plesiolebiasine killifish genera Pituna, Plesiolebias and Maratecoara (Teleostei: Cyprinodontiformes: Rivulidae), with descriptions of nine new species., Zootaxa (1410), pp. 1-41:13-16

COSTA, W.J.E.M., RAMOS, T.P.A., ALEXANDRE, L.C. \&RAMOS, R.T.C.2010. Cynolebias parnaibensis, a new seasonal killifish from the Caatinga, Parnaíba river basin, northeastern Brazil, with notes on sound producing courtship behavior (Cyprinodontiformes: Rivulidae). Neotropical Ichthyology, v. 8, p. 283-288. doi: http://dx.doi.org/10.1590/S167962252010000200006

EIGENMANN, C.H. 1910. Catalogue of the fresh water fishes of tropical and south temperate America. Rep. Princeton Univ. Exped. Patagonia., Princeton, 3(2):375-511.

FONTENELE, O. \& FARIAS, J.O. 1979. Efeitos da barragem Boa Esperança (Guadalupe, Piauí) sobre a Ictiofauna do rio Parnaíba. Bol. Tec, DNOCS, Fortaleza, 37(1):23-29.

FOWLER, H.W. 1941.A collection of fresh-water fishes obtained in eastern Brazil by Dr. Rodolpho von Ihering. Proceedings of The Academy of Natural Sciencies of Philadelphia. V. 93, p.123.199.

FOWLER, H.W. 1954. Os peixes de água doce do Brasil. Arq. Zool. Estado São Paulo. São Paulo. v.6, 4a, p.1-400.

HUBBS, C.L. \& LAGLER, K.F. 2006.Fishes of the Great Lakes region. Ann Arbor: University of Michigan Press. p.1-213.

HUBERT, N. \& RENNO, J.F. 2006. Historical biogeography of South American freshwater fishes. J. Biogeogr., v. 33, p. 1414-1436. doi: http://dx.doi.org/10.1111/j.1365-2699.2006.01518.x

LUCENA, C.A.S. 2003. Revisão taxonômica e relações filogenéticas das espécies de Roeboides grupo-microlepis (Ostariophysi Characiformes, Characidae). Ilheringia, Série Zoologia. 93(3):283308. doi: http://dx.doi.org/10.1590/S0073-47212003000300008

LUCENA, C.A.S. 2007. Revisão taxonômica das espécies do gênero Roeboides grupo-affinis (Ostariophysi, Characiformes, Characidae). Iheringia. Série Zoologia, v. 97, p. 117-136. doi: http://dx.doi.org/10.1590/S0073-47212007000200001

MALABARBA, L.R. \& REIS, R.E. 1987. Manual de técnicas para a preparação de coleções zoológicas. Sociedade Brasileira de Zoologia, Campinas, v. 36, p. 1-14.

MENEZES, R.S. 1955. Lista de peixes de água doce do Piauí. In: PORTO, C. E. - Roteiro do Piauí. Ministério da Educação e Cultura. Ilus., Rio de Janeiro, 188 p.

MENEZES, R.S. 1964. A Pesca e os Peixes da Bacia do rio Parnaíba, Piauí. Chacaras e Quintais. São Paulo, 110(5):747-752.

MENEZES, R.S. 1973. Recursos pesqueiros da bacia do rio Parnaíba (Maranhão - Piauí). Bol. Tec. DNOCS. Fortaleza, 31(1):51-94.

NELSON, J.S.Fishes of the world. 4 ed. Edmonton, Canadá: John Wiley \& Sons, Inc, 2006. 622p.

PAIVA, M.P. 1973. Recursos pesqueiros e pesca na bacia do rio Parnaíba (Brasil). Bol. Cear. Agron. Fortaleza, 14: p.49-82.

PAIVA, M.P. 1976. A pesca na represa de boa Esperança. Revista Brasileira de Energia Elétrica, Rio de Janeiro, (33): p.49-56.

PAIVA, M.P. 1978. A ictiofauna das Grandes Represas Brasileiras. Revista DAE116: p. 49-57.

PINNA, M.C.C. de, \& WOSIACKI.W. 2003. Family Trichomycteridae (Pencil or parasitic catfishes).In: Check List of the Freshwater Fishes of South and Central America, R. E. REIS, S. O. KULLANDER, e C. J. FERRARIS, Jr. (eds.), Porto Alegre: Edipucrs. Porto Alegre, p. 270-290.

PIORSKI, N.M., GARAVELlO, J.C., ARCE, H.M., \& PÉREZ, M.H.S. 2008. Platydoras brachylecis, a new species of thorny catfish (Siluriformes: Doradidae) from northeastern Brazil. Neotropical Ichthyology, 6(3):481-494. doi: http://dx.doi.org/10.1590/S167962252008000300021

RAMOS, R.T.C., RAMOS, T.P.A., ROSA, R.S., BELTRÃO, G.B.M. \& GROTH, F. 2005. Diversidade de Peixes (Ictiofauna) da bacia do rio Curimataú, Paraíba. In: ARAUJO, F.S., RODAL, M.J.N. \&BARBOSA, M.R.V. Análise das variações da biodiversidade do bioma caatinga: suporte das estratégias regionais de conservação. Brasília: Ministério do Meio Ambiente, p. 291-318.

RAMOS, T.P.A. 2012. Ictiofauna de Água Doce da Bacia do Rio Parnaíba. Tese de Doutorado. Universidade Federal da Paraíba, João Pessoa.

REIS, R.E., KULLANDER, S.O., FERRARIS, J. \& CARL, J. 2003. Check List of the freshwater fishes of South and Central America. Porto Alegre: EDIPUCRS. P.1-729. 
ROBERTS, T.R. 1968. The fishes of the Rio Parnaíba. Fortaleza, p. 10 .

ROSA, R.S., MENEZES, N.A., BRITSKI, H.A., COSTA, W.J.E.M. \& GROTH, F. 2003. Diversidade, padrões de distribuição e conservação dos peixes da Caatinga. In: LEAL, I.R., TABARELLI, M. \&SILVA, J.M.C. Ecologia e Conservação da Caatinga. Recife: Editora Universitária da UFPE. p.135-162.

SEMAR-PI; SRH/MMA. 2008 - Secretária do Meio Ambiente e Recursos Hídricos do Piauí. Secretária de Recursos Hídricos do Ministério do Meio Ambiente Caderno Regional - Região Hidrográfica Parnaíba. Resumo Executivo. Piauí. 110 p.
SOARES, R.R. 1987. Dados preliminares sobre a composição da ictiofauna da bacia do rio Parnaíba. In: Anais da Sociedade Nordestina1: p.167-171.

STAECK, W. \& SCHINDLER, I. 2006.Geophagus parnaibae sp. n. a new species of cichlid fish (Teleostei; Perciformes; Cichlidae) from the rio Parnaíba basin, Brazil. ZoologischeAbhandlungen Museum fürTierkunde Dresden. 55, p. 69-75.

VARI, R.P. 1989. Systematics of the Neotropical Characiform Genus Psectrogaster Eigenmann and Eigenmann (Pisces, Characiformes).Smithsonian Contributions to Zoology, 481: p.141. doi: http://dx.doi.org/10.5479/si.00810282.474 